\title{
"You Crossed the Fog Line!"-Kansas, Pretext, and the Fourth Amendment
}

\author{
Melanie D. Wilson*
}

I. INTRODUCTION

"Dropsy testimony" is testimony by a police officer, typically during a suppression hearing, claiming that a defendant dropped illegal drugs, "thus leaving them in plain view or abandoning them ...." After the United States Supreme Court's 1961 landmark decision in Mapp v. Ohio, ${ }^{2}$ in which the Court held that the exclusionary rule applies to the states, in addition to the federal government, there was a reported spike in police dropsy testimony. Irving Younger, former prosecutor, judge, and law professor, ${ }^{3}$ explained the spike this way: Soon after Mapp, "police made the great discovery that if the defendant drops the narcotics on the ground, after which the policeman arrests him, the search is reasonable and the evidence is admissible."4 The implication was that police were distorting the truth to prevent judges from suppressing inculpatory evidence and to save their drug cases from eventual dismissal.

In Kansas, there may be a more modern-day type of dropsy testimony designed to justify pretextual drug investigations of out-ofstate cars with Hispanic drivers. A stop is "pretextual" when officers use

Associate Professor, the University of Kansas School of Law. My sincerest thanks go to Christopher R. Drahozal, Jelani Jefferson Exum, Elizabeth Weeks Leonard, and L.M. Reeves for providing thoughtful and constructive comments on an earlier draft. I also owe many thanks to my talented research assistants Josh A. Bender and Chris Grenz.

1. Donald Dripps, The Case for the Contingent Exclusionary Rule, 38 AM. CRIM. L. REV. 1, n.110 (2001). See also Andrew E. Taslitz, The Expressive Fourth Amendment: Rethinking the Good Faith Exception to the Exclusionary Rule, 76 Miss. L.J. 483, 557 (2006) (explaining that in "dropsy" cases, officers "testify that a fleeing suspect conveniently 'dropped' or abandoned drugs while in flight, thus losing any privacy protection under the Fourth Amendment").

2. 367 U.S. 643 (1961).

3. See Stephen Labaton, Irving Younger, Lawyer, 55, Dies; Judge, Law Professor and Author, N.Y. TIMES, Mar. 15, 1988, Obituaries, available at http://www.nytimes.com/1988/03/15 /obituaries/irving-younger-lawyer-55-dies-judge-law-professor-and-author.html.

4. Irving Younger, Constitutional Protection on Search and Seizure Dead?, TRIAL, Aug.Sept. 1967, at 41 .

5. Id. 
a valid reason for a traffic stop to carry out some other investigatory purpose for which there is no legal justification. ${ }^{6}$ A stop would also be pretextual if an officer lied and said that a traveler committed a traffic violation, creating a false basis to stop a car. ${ }^{7}$ The first pretext is legal, the second unlawful in violation of the Fourth Amendment. ${ }^{8}$ A review of data from the District of Kansas indicates that Kansas police ${ }^{9}$ rely on minor traffic violations as an excuse to stop and look in out-of-state cars and to gain face-to-face interaction with certain travelers whom they speculate may be transporting drugs. Sometimes Kansas police stop a car, citing a dirty tag or a faulty tag light. ${ }^{10}$ Recently, officers have relied on lane violations as grounds for traffic stops. Lane infractions allow Kansas police to stop a car when a driver veers, even just a bit, from his lane of travel and touches or crosses a center line or a "fog line." an officer stops the car for drifting from one lane, the officer engages the occupants with questions about their travel plans, advises them that he will merely issue a warning for the minor infraction, and, having gained their gratitude for the painless warning, asks the occupants for permission to search the car, or their bodies, clothing, or belongings. If, during the stop, the officer ultimately uncovers what he intends to find $^{12}$ - contraband - the defendant is charged with a crime, sometimes in federal court. ${ }^{13}$ At a subsequent hearing to evaluate a defendant's

6. See United States v. Guzman, 864 F.2d 1512, 1515 (10th Cir. 1995) (“A pretextual stop occurs when the police use a legal justification to make the stop in order to search a person or place, or to interrogate a person for an unrelated serious crime for which they do not have the reasonable suspicion necessary to support a stop."), overruled on other grounds by United States v. BoteroOspira, 71 F.3d 783 (10th Cir. 1995).

7. See Patricia Leary \& Stephanie Rae, Toward a State Constitutional Check on Police Discretion to Patrol the Fourth Amendment's Outer Frontier, 69 TEMP. L. REv. 1007, 1009 (1996) (defining pretext as "a legal justification that is used to mask the real, legally unjustifiable motive for a seizure").

8. Guzman, 864 F.2d at 1515; Leary \& Rae, supra note 7, at 1009.

9. Except where otherwise indicated, in this Article "police" includes local, county, state, and federal peace officers who work anywhere within the District of Kansas.

10. See, e.g., United States v. Paez, No. 09-40006-JAR, 2009 WL 1739907, at *1 (D. Kan. June 18, 2009) (Kansas State Trooper conducts stop of tractor trailer for illegible Indiana tag); United States v. Johnson, No. 08-40010-01-RDR, 2009 WL 1468486, at *1 (D. Kan. May 22, 2009) (Potowatomi Tribal Police cite tag light violation and failing to signal as basis for a stop).

11. A "fog line" is the white line on the right-hand side of a road, separating the lane for travel from the shoulder.

12. This inference about the officers' intentions is one drawn from the data, especially the data showing that officers issue warnings, not citations, for fog-line infractions and that they quickly move from a discussion of the infraction to inquiry of possible drug trafficking.

13. More drug cases are prosecuted in state court than in federal court. See, e.g., Office of National Drug Control Policy Drug Policy Information Clearinghouse, State of Kansas Profile of Drug Indicators, June 2008, available at http://www.whitehousedrugpolicy.gov/statelocal $/ \mathrm{ks} / \mathrm{ks} . \mathrm{pdf}$ (showing that in 2006, the federal Drug Enforcement Agency made 255 arrests for drug violations in Kansas while overall there were 11,937 adult drug arrests in the state during that time). 
motion to suppress the contraband, ${ }^{14}$ the officer testifies to his reason for the stop- " "you crossed the fog line," "drifted from your lane of travel," or "failed to maintain a single lane." The officer typically makes no mention of the reasons for selecting this particular car for careful scrutiny. As long as an officer has $a$ legally sufficient reason to stop a car, his ulterior motives in a given case are viewed as irrelevant for purposes of the Fourth Amendment. ${ }^{15}$

This Article urges readers to stand back from any one particular fogline case, in which it appears that an officer acted diligently and perceptively, uncovering a significant crime during a standard traffic stop, and to look for patterns emerging from a series of cases. From this multi-case perspective, it seems that fog-line stops may be nothing more than a pretext for drug investigations. Some of these pretextual stops probably follow from an actual traffic infraction. Other fog-line stops may amount to a new type of police dropsy testimony in that Kansas police come to federal court and offer a post-hoc justification for an otherwise unlawful search that, nevertheless, uncovered contraband. Given the limited data, there is no way to know whether Kansas police are engaging in lawful, but controversial, pretextual stops or, conversely, dishonestly claiming to witness lane drifts that never occurred. In either event, Kansas officers (consciously or subconsciously) appear to be acting on unreliable stereotypes, such as skin color and out-of-state status, in deciding which cars to stop and investigate.

In making a case for increased attention to fog-line (and similar) traffic stops, this Article proceeds in three parts. Part II examines data from orders recently decided in the District of Kansas to show, circumstantially, that Kansas police are using fog-line violations as a ruse to stop out-of-state cars driven by people of Hispanic ethnicity. Part III summarizes the law relevant to pretextual fog-line traffic stops, including federal and state law governing Kansas police. Finally, Part IV offers a few observations about why Kansas police should try harder to avoid pretextual fog-line stops.

\section{RECENT JUDICIAL ORDERS FROM THE DISTRICT OF KANSAS}

This Article is informed by my review of criminal orders deciding motions to suppress evidence issued recently by federal trial judges in

14. The exclusionary rule generally precludes the use of evidence from a defendant's criminal trial when police gathered the evidence by violating the Fourth Amendment and certain other constitutional provisions. See Mapp v. Ohio, 367 U.S. 643 (1961).

15. See Whren v. United States, 517 U.S. 806 (1996) and discussion infra Part III.A. 
the District of Kansas. I reviewed all criminal orders published on the "Recent Opinions" section of the website for the United States District Court for the District of Kansas for the period August 1, 2008 through September 15, 2009 (a period of approximately thirteen months). ${ }^{16}$ I began my review on September 10, 2009. In all, I reviewed 476 orders and culled those for rulings on motions to suppress. ${ }^{17}$ During the applicable time period, the court decided thirty-five motions to suppress. ${ }^{18}$ A list of these thirty-five orders, with accompanying case names, numbers, and other pertinent information, follows this Article as an appendix. Of the court's thirty-five orders, nine (about 26\%) involved evidence seized during a traffic stop, as compared to evidence uncovered during the search of a home or office, or the search of a car for reasons other than a traffic violation. In five of the nine traffic stops (approximately 56\%), Kansas police cited a fog-line infraction or similar lane drift as the reason for the stop. ${ }^{19}$ Although Kansas police purportedly stopped all five vehicles for leaving their lane of travel, when considered as a group, officers appeared to have a different reason for each of the stops. While the sample size is admittedly small, the

16. The orders can be accessed at http://www.ksd.uscourts.gov/ under the Recent Opinions link.

17. In theory, the 476 number would represent every order issued in a criminal case during the specified time because the website is designed to provide access to all publically-available orders from the court. But information obtained from the Clerk's Office, United States District Court for the District of Kansas, indicates that each judge's chambers is responsible for posting its own orders. Therefore, if there is human error in publishing the orders to the website, the errors will result in fewer than all orders on the site. As a result, it is likely that judges in the District of Kansas issued more than 476 criminal orders in the given time period. In addition, sealed orders are unavailable by definition.

18. This number reflects all of the motions to suppress that are available on the court's website in the approximately thirteen-month period. Occasionally, a defendant filed a motion to reconsider a motion to suppress. These motions for reconsideration are also included in the count of orders on motions to suppress.

19. These cases include United States v. Gonzalo Maldonado, No. 09-40031-SAC, 2009 WL 2760798, at *1 (D. Kan. Aug. 26, 2009) (claiming that the defendant crossed over the center line); United States v. Jose Maldonado, 614 F. Supp. 2d 1179, 1180 (D. Kan. 2009) (asserting that car drifted slightly into another lane); United States v. Perales, No. 08-40055-JAR, 2008 WL 4974807, at *1 (D. Kan. Nov. 19, 2008) (asserting that vehicle crossed the fog line); United States v. Rocha, No. 06-40057-RDR, 2008 WL 4498950, at *1 (D. Kan. Oct. 2, 2008) (claiming that recreational vehicle crossed the fog line); United States v. Diaz, No. 08-10100-MLB, 2008 WL 3154664, at *1 (D. Kan. Aug. 5, 2008) (asserting that car crossed the fog line and center line).

The other four orders involving traffic stops revealed that vehicles were cited for: (1) an illegible tag, United States v. Paez, No. 09-40006-JAR, 2009 WL 1739907, at *1 (D. Kan. June 18, 2009); (2) a positive sniff from a drug-dog in a parking lot, United States v. Johnson, No. 08-40010RDR, 2009 WL 1468486, at*1 (D. Kan. May 22, 2009); (3) speeding in a work zone while under surveillance by the Drug Enforcement Agency, United States v. Beltran-Aguilar, No. 08-20106KHV, 2009 WL 103642, at *2 (D. Kan. Jan. 14, 2009); and (4) suspicious activity while parked in a parking lot, United States v. Salazar, No. 08-20084-KHV, 2009 WL 352605, at *1 (D. Kan. Feb. 12, 2009). 
orders are informative. They show a pattern-in all five cases, Kansas police targeted out-of-state cars driven by people of Hispanic ethnicity so that they could obtain the occupants' permission to search the vehicles for drugs. ${ }^{20}$

\section{A. Recent Pretextual Police Stops in Kansas}

During the thirteen months reviewed, at least nine minor traffic infractions ultimately resulted in felony criminal cases in federal court. In eight of those nine traffic-stop cases (approximately 89\%), the defendants appear to have been of Hispanic ethnicity. ${ }^{21}$ In five of the nine cases, the federal criminal case began with a lane violation, and $100 \%$ of the defendants and the other occupants of the vehicles in those lane-violation cases appear to have been Hispanic. The defendants and other occupants include: Jose Maldonado; Gonzalo Maldonado and Manuel Garcia; Felipe Perales; Luis Diaz and Stephen Demalleo; and Julian Rocha, Ericka Rocha, and Gerardo Gaxiola. ${ }^{22}$ The high percentage of Hispanic defendants stands out because Kansas has a relatively small Hispanic and Latino population. In 2008, the population of Kansas was approximately 2,802,134, and persons of Hispanic or

20. I wondered how officers could see into cars from significant distances to select certain drivers. An interview of a current federal public defender in the District of Kansas revealed that often the police pull up beside a car before falling back and activating the patrol car's lights or siren, signaling for the citizen driver to pull over. The federal defender's information is corroborated by the facts in the Diaz case in which the Trooper pulled alongside the car occupied by defendants Demalleo and Diaz. See Defendants' Memorandum in Support of Joint Motion to Suppress Evidence, United States v. Diaz [and Demalleo], No. 08-10100-MLB, 2008 WL 3154664 (D. Kan. Jul. 7, 2008).

21. By Hispanic, I mean to suggest ancestral ties to Mexico, Puerto Rico, Cuba, or South or Central America. This observation rests primarily on the names of the defendants, each of whom was identified by a common Hispanic surname. But in some cases, the ethnicity of the defendant was confirmed by his own pleading (usually a brief in support of the motion to suppress), the judge's order, or the transcript of the hearing on the motion to suppress. (When readily available, these court documents were accessed through Pacer.) For instance, in the case of defendant Perales, the judge's order, which denies the defendant's motion to suppress, implies that the defendant's primary language is Spanish, supporting the inference that he is of Hispanic ethnicity. See Perales, 2008 WL 4974807 , at $* 2$ (noting that during a post-arrest interview of the defendant, an agent who is "fluent in Spanish" was available, but not needed, to interpret). In United States v. Gonzalo Maldonado, the judge's order indicates that the driver of the vehicle spoke little English, supporting the inference that the defendant is Hispanic. See 2009 WL 2760798, at*1. In the case of Jose Maldonado, the transcript of the hearing on the motion to suppress reveals cross-examination questions from the defendant's lawyer confirming that the defendant's ethnicity is Hispanic and references to the defendant's "limited knowledge of the English language." Jose Maldonado, 614 F. Supp. 2d at 1183. And, in the case of Julian Rocha, the court found that the occupants of the recreational vehicle did not have "trouble speaking or understanding English." Order of October 2, 2008 at 6, Rocha, 2008 WL 4498950, at *2.

22. See cases cited supra note 21 . 
Latino origin made up only $9.1 \%$ of the total. ${ }^{23}$ Moreover, a study of police profiling in Kansas published in 2003 found that persons of Hispanic ethnicity experience more police profiling ${ }^{24}$ than black or white citizens. $^{25}$

In each of the five fog-line cases, a Kansas officer ${ }^{26}$ reportedly stopped the defendant's car because the driver drifted from a lane of travel and breached K.S.A. section 8-1522(a), requiring drivers to stay "as nearly as practicable entirely within a single lane." 27 Despite the lane drifts, in every case, the officer decided not to issue the driver a ticket. Instead, the driver was given a "warning." 28 The officer then questioned the car's occupants about their travel plans, usually including their place of departure and their intended destination. In every case, the car was traveling to or through Kansas from out of state. Jose Maldonado was driving from Texas with a Texas license plate. Julian Rocha was riding in a rented recreational vehicle driven by Gerardo Gaxiola. Rocha and Gaxiola were traveling from California, and the R.V. was rented and registered in California. Defendant Perales was driving from California to Kansas City. Defendant Demalleo was riding in a car driven by Luis

23. See United States Census Bureau, http://quickfacts.census.gov/qfd/states/20000.html (last visited March 11, 2010). The use of census statistics as a benchmark of comparison for racial profiling is not without critics. See A Multijurisdictional Assessment of Traffic Enforcement and Data Collection in Kansas, The Police Foundation, at 11, Feb. 2003 [hereinafter $A$ Multijurisdictional Assessment] (stating that the use of census data "will not serve as reliable benchmarks" and relying on surveys of highway transient traffic as a comparator).

24. The study defined racial profiling as "selectively stopping, questioning, and searching people on the basis of arbitrary minor offenses and the color of their skin." A Multijurisdictional Assessment, supra note 23 , at $\mathrm{xv}$.

25. Id. at 66. "The data strongly suggest that the Emporia police are targeting Hispanic motorists." Id. at 77, 80. The data showed that "[t]he Olathe Police Department is stopping more Black and Hispanic motorists than would be expected on the basis of their presence in the transient population." Id. at 90. "[T]here are large disparities with regard to Hispanic motorists at the two locations with the largest number of stops" by the Osage County Sheriff's Department. Id. at 105 . "[T]here are serious disparities shown by the [Kansas Highway Patrol] in the stopping of both Black and Hispanic motorists." Id. at 127. But see id. at 65-66 (noting that the Wichita Police Department was taking measures to "fight against racial/ethnic profiling" which were paying off and that stops of Hispanics were "at the lower range of the benign area").

26. In three of the five cases, the officer was a member of the Kansas Highway Patrol. In one, the officers worked for the Wichita Police Department. In the remaining case, the officer was an employee of the Shawnee County Sheriff's Office.

27. This law provides that when a roadway is divided into two clearly marked lanes of traffic, "[a] vehicle shall be driven as nearly as practicable entirely within a single lane and shall not be moved from such lane until the driver has first ascertained that such movement can be made with safety.” KAN. STAT. ANN. § 8-1522(a) (2008).

28. Compare this $100 \%$ warning rate with the fact that out of all stops (traffic and pedestrian) conducted by officers of the Wichita Police Department Jan. 1-June 30, 2001, 57.1\% resulted in the issuance of a citation. See Brian L. Withrow, The Wichita Stop StUdy 39 (Midwest Criminal Justice Institute, Jan. 2002). Interestingly, Wichita police also issued a disproportionate number of warnings, rather than citations, to Hispanic citizens. See id. at 41. 
Diaz. Demalleo and Diaz, described in the judge's order as two welldressed men, were driving from Denver, returning to Missouri, where the men had rented a car for the trip. Gonzalo Maldonado, with Manuel Garcia as his passenger, was stopped by the Kansas Highway Patrol on his way from Sacramento, California to Kansas City. ${ }^{29}$

In each case studied, after an officer questioned the occupants and checked their driver's licenses and the car's registration, the officer returned the documents and took "a couple of steps back towards the patrol car" ${ }^{\prime 30}$ before re-engaging the occupants to ask more questions. ${ }^{31}$ In each of the five fog-line cases, the officers' follow-up questions were directed at uncovering evidence of drug trafficking. For instance, in the case involving defendants Gonzalo Maldonado and Garcia, the officer asked "whether there was anything illegal in the vehicle, such as 'cervesa,' 'pistoles,' drugs, or illegal aliens." 32 In the case of defendant Rocha, the officer asked whether there were "any drugs or contraband.",33 After this seemingly scripted give-and-take, in each case, the Kansas

29. See cases cited supra note 19.

30. Defendants' [Diaz and Demalleo] Memorandum in Support of Joint Motion to Suppress Evidence, supra note 20, at *2 (after returning the occupants' licenses and the car's rental agreement and giving Diaz a warning for failure to maintain a lane, "Trooper Duffy began walking towards the back of the Chrysler, only to turn around and ask Mr. Diaz if he could ask a couple of questions"). See also United States v. Gonzalo Maldonado, No. 09-40031-SAC, 2009 WL 2760798, at *3-4 (D. Kan. Aug. 26, 2009) (explaining that Trooper issued driver a written warning for failing to maintain a lane and for a registration violation, returned the driver's paperwork, and said "'No ticket. Just a warning. Thank you." Then, officer walked to the rear of the vehicle, returned to the passenger window, and asked if "he could ask the men a few more questions"); United States v. Jose Maldonado, 614 F. Supp. 2d 1179, 1181 (D. Kan. 2009) (officers returned Maldonado's license and insurance, told him to continue on his way, and then "re-engaged" him to ask more questions about his travel and to ask for consent to search the vehicle); United States v. Perales, No. 08-40055-JAR, 2008 WL 4974807, at *2 (D. Kan. Nov. 19, 2008) ("Trooper Henderson explained that he did not intend to give defendant a citation; rather he wanted assurance that defendant was not impaired" and after "returning defendant's documents" Trooper Henderson "walked to the rear of the Toyota before returning to ask defendant if he had any illegal drugs in the vehicle"); United States v. Rocha, No. 06-40057-RDR, 2008 WL 4498950, at *5 (D. Kan. Oct. 2, 2008) (noting that the deputy returned all of the occupants' documents and gave the driver a warning ticket for failing to maintain a single lane of travel before telling the driver "thank you" and stepping aside before returning to ask whether the driver "had any drugs or contraband").

31. Presumably, the officers ended the stop by returning the documents and telling the occupants they were free to leave because a seizure that is lawful at its inception may become unconstitutional (in violation of the Fourth Amendment) if its duration exceeds a reasonable time needed to investigate the basis for the stop. See United States v. Sharpe, 470 U.S. 675, 686 (1985); Terry v. Ohio, 392 U.S. 1, 18-19 (1968); see also United States v. Chavira, 467 F.3d 1286, 1290 (10th Cir. 2006) (a seizure justified solely by the interest in issuing a warning ticket can become unlawful if prolonged beyond the time reasonably required to complete the mission, so a driver must be permitted to leave after a routine traffic stop unless an officer has reasonable suspicion or the driver consents to further questioning).

32. See Gonzalo Maldonado, 2009 WL 2760798, at*4.

33. Rocha, 2008 WL 4498950, at*2. 
officer sought to search the vehicles. ${ }^{34}$ In three of the cases, there was some question about the ability of the car's occupants to understand English. $^{35}$

Taking the fog-line cases as a whole, the officers' issuance of warnings rather than tickets appears designed to take advantage of human nature. ${ }^{36}$ A warning causes the driver to relax and to feel grateful to the officer. Sensing an opportunity to circumvent the need for probable cause, the officer then asks the driver for consent. ${ }^{37}$ The driver, now feeling like he owes the officer something in return for the simple warning, agrees to the search. Especially in cases involving people whose first language is not English, the colloquy seems destined to end in a search, regardless of whether voluntary and knowing consent is given. ${ }^{38}$

The officers' intent to conduct a search is, perhaps, best illustrated in the one case (of the five) that occupants refused to continue to answer the officer's questions and never consented to a search. In United States $v$.

34. In four cases the officer asked for permission to search. In the fifth case, the defendant began to drive away before the officer could ask.

35. In the case of defendant Felipe J. Perales, the district court noted that the defendant answered the trooper's questions about drugs "without difficulty communicating." Perales, 2008 WL 4974807 , at $* 2$. In the case of Jose Maldonado, the court noted that the defendant's silence in the face of police questioning may have been due to "his limited knowledge of the English language." Jose Maldonado, F. Supp. 2d at 1183. And, in the case of Gonzalo Maldonado and Manuel Garcia, the officer was told by the passenger that the driver "did not communicate very well in English." Gonzalo Maldonado, 2009 WL 2760798, at *1.

36. In Kansas officers have extensive discretion in determining whether to issue a citation or just a warning. It is unclear in what percentage of traffic stops officers decide on the warning. In an extensive study of traffic enforcement in Kansas published in 2003, the researchers indicated that there was no uniform policy for collecting and maintaining data about tickets versus warnings. See A Multijurisdictional Assessment, supra note 23, at 12 . The study noted that New Jersey and Arizona showed high percentages of warnings. Id. at 13 (reporting that Arizona police issue warnings in $75 \%$ of stops and that in New Jersey the percentage is approximately 63\%). Data collected by the Wichita Police Department for the period January 1, 2001 through June 30, 2001 (including police stops of both cars and pedestrians) revealed that "[m]ost stops result in the issuance of a citation." WITHROW, supra note 28, at Executive Summary.

37. Studies have shown that people are likely to comply with requests from authority figures and that people feel pressure when dealing with police officers. See David K. Kessler, Free to Leave? An Empirical Look at the Fourth Amendment's Seizure Standard, 99 J. CRIM. L. \& CRIMINOLOGY 51, 63-64 (2009) (reviewing some of these studies and reporting results of his own empirical findings).

38. The fact that an officer requested permission to search in four of the five fog-line cases is notable because officers do not ask to search during every traffic stop. For instance, data collected in 2000 from the Wichita Police Department indicated that their officers conducted searches in only about $12.5 \%$ of car stops and that many of these searches were justified as incident to the arrest of the car's occupants. WITHROW, supra note 28, at Executive Summary. The Wichita study also revealed that while Wichita Police did not stop a disproportionate number of Hispanic drivers, both black and Hispanic citizens were more likely to be searched than were non-black and non-Hispanic persons. Id. 
Diaz, an officer stopped a Chrysler, reporting that the car crossed over the center line by at least six inches, at least twice. ${ }^{39}$ After checking the driver's and passengers' paperwork, the officer returned the documents and issued a warning for the infractions. ${ }^{40}$ Then, the officer "took a couple of steps back towards his patrol car and heard the gear selector shift." ${ }^{41}$ Hearing the driver begin to leave, the officer asked "if he could ask some more questions[,]" but the driver refused, saying "we're done." ${ }^{42}$ Intent on searching the car, the officer ordered the driver to "take the keys out of the ignition, hand them over ... and put the car in park." 43 The officer then called another officer to bring a drug dog to the scene to sniff for drugs. ${ }^{44}$

In other words, in all five of the fog-line cases, the officers appeared to be looking for drugs without probable cause to believe that drugs would be present in these particular vehicles. ${ }^{45}$ Sometimes it took more than one search. ${ }^{46}$ Sometimes it took an extended period of time. ${ }^{47}$ Sometimes officers searched despite the defendant's refusal to consent, ${ }^{48}$ but officers eventually found illegal drugs in each of the five vehicles. ${ }^{49}$

In two of the five fog-line cases, the defendants later succeeded in excluding the contraband from use at trial. The trial judge suppressed

\footnotetext{
39. No. 08-10100-MLB, 2008 WL 3154664, at*1 (D. Kan. Aug. 5, 2008).

40. $I d$.

41. Id.

42. Id.

43. $I d$.

44. Id.

45. Racial and ethnicity profiling is a nationwide concern. See Timothy P. O'Neill, Vagrants
} In Volvos: Ending Pretextual Traffic Stops and Consent Searches of Vehicles in Illinois, 40 LOY. U. CHI. L.J. 745, 747, 771-72 (2009) (reciting literature and studies of "disturbing racial disparities in traffic enforcement" including study of stops throughout Illinois in which officers "utilized consent searches against Hispanic drivers more than twice as often as against Caucasian drivers" although "searches of Caucasians were twice as likely to discover contraband as were the searches of minorities").

46. See Transcript of Proceedings (Feb. 26, 2009), 22 \& Transcript of Proceedings (Mar. 12, 2009), 26-30, United States v. Jose Maldonado, 614 F. Supp. 2d 1179 (D. Kan. 2009) (No. 0810216-01) [hereinafter Transcript of Proceedings] (on file with author) (three officers worked two different drug dogs on the vehicle until one of the dogs finally alerted to drugs; one police report was altered, making it appear that it took fewer than three searches to find drugs).

47. Id. See also United States v. Gonzalo Maldonado, No. 09-40031-SAC, 2009 WL 2760798, at *3-4 (D. Kan. Aug. 26, 2009) (explaining how trooper searched car for about ten minutes, including its front and back seats, trunk and undercarriage and then asked the two defendants to follow him to a place where he could look under the car, which was about fifteen miles from the place of the stop).

48. See United States v. Diaz, No. 08-10100-MLB, 2008 WL 3154664, at*1 (after officers returned occupants' documents and indicated defendants could leave, officer directed driver to put the car in park and step out).

49. Of course, these cases provide no insight into the number of cars with Hispanic occupants that were searched but revealed no contraband. 
the evidence after finding that the officers violated the defendant's Fourth Amendment rights on the way to uncovering the evidence. In Diaz, the judge granted the defendants ${ }^{, 50}$ joint motion to suppress crystal methamphetamine and other drug-related evidence. ${ }^{51}$ Although the judge determined that the initial stop was legally justified by the fog-line violation, he also ruled that after the officer issued the defendants a warning citation, "Diaz did not agree to further questioning and was ordered [without reasonable cause] to put the car in park and surrender the keys." ${ }^{52}$ Because the additional questioning and continued seizure of car and occupants was neither consensual nor supported by reasonable suspicion, the Kansas officer violated the Fourth Amendment by continuing to detain the car so that he could subject it to a drug-dog sniff and subsequent search.

In United States v. Jose Maldonado, another district court judge granted the defendant's motion to suppress methamphetamine and cocaine. ${ }^{53}$ At the hearing on the motion, officers claimed that they stopped Maldonado because he committed a lane violation. The judge suppressed the evidence after finding that one officer's testimony was not credible. The judge explained:

The government argues that the officers had probable cause to stop the vehicle because the left side tires of Maldonado's vehicle drifted over the center line on at least one occasion, and he was weaving within his own lane. However, prior to the alleged drifting of Maldonado's vehicle, Officer Cooper testified that the only reason he initially followed Maldonado was because he had a Texas license plate. Indeed, he was parked on an exit ramp and pulled onto the roadway for that reason alone. And, this is the only portion of Officer Cooper's testimony that the court finds credible.

This Article applauds the judges' rulings and seeks to show why Kansas trial judges are right to scrutinize fog-line and similar traffic stops carefully and to suppress evidence whenever they doubt officers' testimony about the circumstances of a stop or the Fourth Amendment reasonableness of other police behavior. Whether the officers' pretextual

50. Defendants were driver and occupant of the car. Id.

51. Id. at *3.

52. Id. at $* 2$.

53. 614 F. Supp. 2d 1179, 1184 (D. Kan. 2009).

54. Id. at 1182. But see United States v. Gonzalo Maldonado, No. 09-40031-SAC, 2009 WL 2760798, at*1-2 (D. Kan. Aug. 26, 2009) (rejecting the defendant's argument that officer acted in violation of the Fourth Amendment in following vehicle, which was traveling from California, for two to three minutes before witnessing a fog-line violation, noting that officer did not need reasonable suspicion to follow the car). 
stops are based on actual or phantom violations, the data suggests that Kansas officers are relying on these infractions to stop a disproportionate number of Hispanic drivers of out-of-state cars.

\section{B. The Deceptively Attractive Nature of Fog-line Violations}

While in five of nine traffic stops, officers cited a fog-line violation as the reason for the stop, ${ }^{55}$ fog-line stops were much more likely to result in the suppression of evidence than were other traffic infractions or other cases based on traditional probable cause. In the thirteen-month period studied, judges in the District of Kansas denied 29 of $35(83 \%)$ of motions to suppress, thus allowing the introduction of contraband against the defendants in each of those cases. ${ }^{56}$ Of thirty-five motions, judges granted only three outright and granted, in part, another three. ${ }^{57}$ Nevertheless, in fog-line cases, judges granted the defendants' motions in two of five cases. ${ }^{58}$ In other words, despite the extensive leeway the law gives officers to make traffic stops for even the smallest traffic infraction, ${ }^{59}$ in $40 \%$ (two of five) of the federal cases in which Kansas police relied on a fog-line violation to justify such a stop, the District Court of Kansas ruled that officers had overreached and violated the federal Constitution in their vigor to uncover a more serious crime. ${ }^{60}$ In Fourth Amendment parlance, the officers acted "unreasonably." Thus, whether consciously or subconsciously, Kansas federal district court judges expressed disfavor of fog-line cases through their rulings on motions to suppress evidence.

Unless officers are aware that fog-line cases have met with successful motions to suppress a disproportionately large percentage of the time, "fog-line testimony" might seem to be an ideal justification for a stop. When the driver of a car violates a traffic law, even a very minor one, the violation gives the police reasonable grounds to "seize" the car. $^{61}$ A legal stop gives the officer an opportunity to look in and smell

55. See supra note 19 (citing nine District of Kansas cases involving traffic stops).

56. See Appendix infra (citing thirty-five motions, twenty-nine of which were denied).

57. See Appendix infra (citing thirty-five motions, three of which were granted outright, and another three which were granted in part).

58. See Jose Maldonado, 614 F. Supp. 2d at 1184 (granting the defendants' motion to suppress); United States v. Diaz, No. 08-10100-MLB, 2008 WL 3154664, at*3 (D. Kan. Aug. 5, 2008) (granting defendants' motion to suppress).

59. See discussion infra at Part III.

60. See Jose Maldonado, 614 F. Supp. 2d at 1183-84; Diaz, 2008 WL 3154664 at *2-3.

61. "Although a traffic stop is considered a seizure for Fourth Amendment purposes, a traffic infraction provides reasonable suspicion for a law enforcement officer to conduct the investigatory detention." State v. Tinoco, No. 100,435, 2009 WL 1591644, at *2, 208 P.3d 361 (Kan. Ct. App. 
the vehicle's interior and to get as close as a few inches from the car's occupants. A single fog-line violation provides the police with a chance to ask the occupants questions about their intended destination, their reasons for traveling, their plans upon arrival, and, importantly, whether they will agree to a search of their vehicle, purse, clothing, etc. An added bonus, especially in Kansas, where it is often quite windy, is that everyone occasionally veers from his own lane of traffic. ${ }^{62}$ Thus, if the police wait long enough, they can often rely on a fog-line infraction as a legitimate reason to stop almost any car or driver. Also, because there is no prohibition against following a car to observe it, ${ }^{63}$ it is conceivable that nervousness alone may effectively "force" many drivers, especially minorities and people who are generally fearful of police, to veer, at least a little, from their lane of travel when they normally would have no trouble maintaining a single lane.

From a proof standpoint, a fog-line violation would seem to be ideal for the prosecution. Such violations require no special evidence, no forensics or video proof. Whereas speeding violations are typically accompanied by radar evidence, and driving under the influence violations are proven by breathalyzer or blood/alcohol proof, fog-line violations typically are established by the officer's testimony alone. Even when an officer provides video to support the stop, the traffic violation is usually missing from the video. ${ }^{64}$ The officer often activates the camera by turning on his lights or siren, after the alleged infraction. Even tag violations and infractions for following too closely would probably be visible in the video, unlike lane drifts.

2009) (table decision) (citing City of Norton v. Wonderly, 172 P.3d 1205, 1209 (Kan. Ct. App. 2007)). See also State v. Marx, 215 P.3d 601, 605 (Kan. 2009) (explaining that a "traffic violation provides an objectively valid reason to effectuate a traffic stop, even if the stop is pretextual"). See also Whren v. United States, 517 U.S. 806 (1993), discussed infra at Part III.A.

62. At the hearing on Julian Rocha's motion to suppress, the defendant called an expert witness who testified that when winds reach forty-five miles per hour, "all vehicles would probably deviate from their lane." United States v. Rocha, No. 06-40057-RDR, 2008 WL 4498950, at *3 (D. Kan. Oct. 2, 2008). See also Emily Van Zandt \& Karen Dillon, Study finds slowdown in Kansas wind speed, KAN. CitY STAR, Jul. 20, 2009, at A4 (quoting Mary Knapp, Kansas state climatologist as saying that Kansas is the "third-windiest state in the U.S." and indicating that wind speeds average eleven to twelve miles per hour, but in 2009 meteorologists recorded a gust of 120 miles per hour and another gust of ninety miles per hour that lasted one minute).

63. Following a car or individual is not a search or seizure protected by the Fourth Amendment.

64. For instance, in the case of Julian Rocha, the officer's car was equipped with a video camera but none of the three alleged fog-line violations was captured on the video, supposedly because the video was turned on only after the traffic violations, when the officer activated the emergency lights on the police car. Nevertheless, at the hearing on the motion to suppress, the video actually began when the RV was already stopped. Rocha, 2008 WL 4498950, at *2. Nevertheless, the judge deemed the evidence sufficient to deny the defendant's motion to suppress. Id. at *6. 
The lack of tangible evidence of fog-line infraction makes them uniquely difficult to refute. An officer's word would appear to be more than adequate to establish reasonable suspicion by the applicable preponderance-of-the-evidence burden of proof. ${ }^{65}$ Because most of Kansas is flat and breezy, it is easy to believe that a car left its lane of travel, even if it did not. A defendant who contradicts an officer's testimony with a claim that he or she did not cross the fog line does little more than generate images of childhood disputes-"Yes, you did. No, I did not. Yes, you did!" When there is no independent evidence to contradict an officer's sworn testimony ${ }^{66}$ there is no reason for the judge to doubt the officer's credibility, especially considering that the judge now knows that contraband was found in the car (or on the defendant) and that application of the exclusionary rule will, in all likelihood, doom the government's case. ${ }^{67}$ Particularly for defendants facing serious charges, their inherently-biased testimony is highly unlikely to overcome an officer's version of events.

Because fog-line violations are easy to believe and difficult to refute, unscrupulous officers might be tempted to adopt them as a favorite explanation for traffic stops, particularly when they do not have other reasonable grounds to believe that the car's occupants are committing a crime. Even if Kansas police do not distort the truth, claiming phantom fog-line violations, officers appear to pre-select certain drivers and then use fog-line infractions to justify pretextual drug investigations.

\section{THE APPLICABLE LAW}

Supreme Court precedent and evolving law in both the Tenth Circuit and the state courts of Kansas encourage officers to rely on fog-line violations as grounds to subject a car to a traffic stop. The United States Supreme Court and the Tenth Circuit have given police extensive discretion to conduct pretextual stops for all types of traffic infractions, and the Tenth Circuit and Kansas appellate courts permit officers to prove fog-line infractions with cursory testimony.

65. See United States v. Matlock, 415 U.S. 164, 177 (1974) (describing government's burden of proof in motions to suppress as preponderance of the evidence).

66. Typically, the only witnesses to the traffic stop and subsequent search will be the police and the occupants of the car.

67. In both fog-line cases in which the court granted the defendant's motion to suppress, the government later dismissed the case, presumably because evidence was lacking to proceed to trial. 


\section{A. United States Supreme Court Precedent}

The Supreme Court's holdings in Delaware v. Prouse ${ }^{68}$ and Whren v. United States $^{69}$ inform any discussion of whether police have acted legally when "seizing" a car or truck in a traffic stop and subsequently subjecting both vehicle and occupants to an investigation, related or unrelated to the officer's purported reason for the stop. ${ }^{70}$ In Prouse, the Court declared it "unreasonable," and therefore a violation of the Fourth Amendment, ${ }^{71}$ for a police officer to seize a car without probable cause or reasonable suspicion to believe "that the car is being driven contrary to the laws governing the operation of motor vehicles or that either the car or any of its occupants is subject to seizure or detention in connection with the violation of any other applicable law." ${ }^{, 2}$ The officer in Prouse violated the Fourth Amendment because he stopped a car without observing any traffic or equipment violation or any other suspicious activity. ${ }^{73}$ The stop was held to be an unconstitutional intrusion on Fourth Amendment freedoms after the officer forthrightly admitted that he "saw the car in the area and wasn't answering any complaints," so he chose to stop the car. ${ }^{74}$

The mandate of the Prouse decision was clear. In the run-of-the-mill case, ${ }^{75}$ police need "at least articulable and reasonable suspicion" that the driver or occupants of the car are violating a law before they can legally conduct a stop. ${ }^{76}$ Unbridled police discretion to stop any car, at any time, even in the interest of public safety, is a breach of the Fourth Amendment. The Supreme Court later explained Prouse: "The officer's

\footnotetext{
68. 440 U.S. 648 (1979).

69. 517 U.S. 806 (1996).

70. In Brendlin v. California, 551 U.S. 249, 251 (2007), the Court held that a passenger in a car, as well as the driver of the vehicle, is seized for purposes of the Fourth Amendment when a police officer conducts a traffic stop. Prouse had made clear that a Fourth Amendment seizure occurs when a car is stopped and its occupants are detained, even if the stop "is limited and the resulting detention quite brief." 440 U.S. at 653.

71. Id.; see U.S. CONST. amend. iv ("The right of the people to be secure in their persons, houses, papers, and effects, against unreasonable searches and seizures, shall not be violated ....”); see also KAN. CONST. Bill of Rights $\S 15$ (prohibiting unreasonable government searches and seizures).

72. Prouse, 440 U.S. at 650.

73. Id.

74. Id. at $650-51$.

75. Id. at 657,663 (expressly distinguishing suspicionless stops of vehicles at roadblocks "where all vehicles are brought to a halt").

76. Id. at 663 .
} 
conduct in that case was unconstitutional primarily on account of his exercise of "standardless and unconstrained discretion.",77

The impact of the Prouse decision was marginalized twenty-five years later, when the Supreme Court unanimously decided Whren $v$. United States. ${ }^{78}$ In Whren, the Court held that the subjective intentions of an officer in conducting a Fourth Amendment seizure "play no role in ordinary, probable-cause Fourth Amendment analysis."79

The defendants in Whren had argued that civil traffic regulations should be treated differently than instances in which probable cause or reasonable suspicion rests on other, more significant grounds. They contended:

[T] he use of automobiles is so heavily and minutely regulated that total compliance with traffic and safety rules is nearly impossible, a police officer will almost invariably be able to catch any given motorist in a technical violation. This creates the temptation to use traffic stops as a means of investigating other law violations, as to which no probable cause or even articulable suspicion exists. ${ }^{80}$

The Court rejected this argument and confirmed that breach of a simple traffic regulation can provide an officer with reasonable grounds for a stop, regardless of the real motives of the police for choosing a particular car. ${ }^{81}$ After Whren, police still need an articulable and reasonable basis to conduct a traffic stop, but any "civil traffic violation" can suffice to create that reason. ${ }^{82}$ It is legally irrelevant that an officer uses a traffic violation to investigate his or her hollow hunches that a driver is committing a more serious offense, such as drug trafficking. ${ }^{83}$ Thus, reading Prouse with Whren illustrates that while a police officer cannot stop every car she chooses just because she has a "feeling" that a stop will expose a crime, she is authorized to seize a car and its passengers any time the officer sees a traffic violation or has other reasonable grounds to believe that the car violated a rule of the road. ${ }^{84}$

77. City of Indianapolis v. Edmond, 531 U.S. 32, 39 (2000).

78. 517 U.S. 806 (1996).

79. Id. at 813 .

80. Id. at 810

81. Id. at 813

82. Id. at 808

83. Id. at $811-12$.

84. See also United States v. Ozbirn, 189 F.3d 1194, 1197 (10th Cir. 1999) (providing the Tenth Circuit's version of this standard: "[A] traffic stop is reasonable under the Fourth Amendment at its inception if the officer has either (1) probable cause to believe a traffic violation has occurred ... or (2) a reasonable articulable suspicion that 'this particular motorist violated any one of the multitude of applicable traffic and equipment regulations of the jurisdiction"” (citation 
After Whren, reasonable grounds for a traffic stop are lacking only when there is no traffic violation and no other reasonable basis to believe that a crime is being committed. Of course, if an officer falsely claims to see a violation when she does not, there is no reasonable suspicion or probable cause for a stop. ${ }^{85}$

\section{B. Tenth Circuit Precedent}

The Tenth Circuit's version of Whren and its application of fog-line statutes in states within the circuit encourage Kansas police to cite lane drifts as grounds for a traffic stop.

\section{The Tenth Circuit's Version of Whren}

For about a decade before the decision in Whren, Tenth Circuit ${ }^{86}$ precedent protected citizens against pretextual government searches and seizures. Noting that pretextual stops "permit arbitrary intrusions [risking that] thousands of everyday citizens who violate minor traffic regulations would be subject to unfettered police discretion as to whom to stop," the Tenth Circuit declared that pretextual stops by individual officers were "unreasonable within the meaning of the Fourth Amendment." ${ }^{, 87}$ While recognizing that "requiring at least a minor traffic offense" provides "some objective limitation on police intrusions," the Tenth Circuit, at that time, found such limits too meager. ${ }^{88}$ Instead, the court evaluated pretextual stops by asking "whether under the same circumstances a reasonable officer would have made the stop in the absence of the invalid purpose." 89 If a reasonable officer would have been uninterested in pursuing the traffic violation absent the hope of finding drugs, other contraband, or some other serious violation of law, then the seizure and search were deemed unconstitutional. ${ }^{90}$

omitted)).

85. See Whren v. United States, 517 U.S. 806, 812 (1996) (acknowledging that if an officer "really had not seen" a traffic violation, then there is no pretext for the stop but also no probable cause for it).

86. The Tenth Circuit includes: Kansas, Oklahoma, Colorado, New Mexico, Utah, and Wyoming.

87. United States v. Guzman, 864 F.2d 1512, 1516 (10th Cir. 1988), overruled on other grounds by United States v. Botero-Ospina, 71 F.3d 783 (10th Cir. 1995) (en banc).

88. Id. at 1516.

89. Id. at 1517 (quoting United States v. Smith, 799 F.2d 704, 709 (11th Cir. 1996)).

90. Id. 
In 1995, even before the Supreme Court decided Whren, the Tenth Circuit changed its position. In an en banc decision, the court in United States v. Botero-Ospina, "adopt[ed] a new test" for "determining when an initial stop of an automobile violates the Fourth Amendment." 91 Pursuant to the new standard, "a traffic stop is valid under the Fourth Amendment if the stop is based on an observed traffic violation or if the police officer has reasonable articulable suspicion that a traffic or equipment violation has occurred or is occurring." it "irrelevant" that an officer held a subjectively improper motive in addition to an objectively valid basis for a stop. ${ }^{93}$ The Tenth Circuit said: "Our sole inquiry is whether this particular officer had reasonable suspicion that this particular motorist violated 'any one of the multitude of applicable traffic and equipment regulations' of the jurisdiction." 94

The Tenth Circuit insisted that despite the change in position, citizens were adequately protected against arbitrary police intrusion on privacy and liberty because "if an officer's initial traffic stop, though objectively justified by the officer's observation of a minor traffic violation, is motivated by a desire to engage in an investigation of more serious criminal activity, his investigation ... will be circumscribed by Terry [v. Ohio]'s scope requirement." ${ }^{95}$ In Terry, the Supreme Court held that a stop, which is reasonable at its inception, may violate the Fourth Amendment "by virtue of its intolerable intensity and scope."

\section{The Tenth Circuit's Fog-line Cases}

While the Whren and Botero-Ospina decisions make any violation of the rules of the road an acceptable basis for a Fourth Amendment seizure, other decisions from the Tenth Circuit make a fog-line infraction a particularly attractive excuse for an investigatory stop. The Tenth Circuit has interpreted Kansas's traffic laws ${ }^{97}$ in a way that allows police

91. 71 F.3d 783, 785 (10th Cir. 1995).

92. Id. at 787 .

93. Id. Apparently a majority of the Tenth Circuit abandoned the old Guzman test, finding it "unworkable" because of disparate application of the standard by the district courts and because in the court's view, it interfered with principles of federalism. See Leary \& Rae, supra note 7, at 1017 (critiquing the Botero-Ospina decision).

94. Botero-Ospina, 71 F.3d at 787 (citing Delaware v. Prouse, 440 U.S. 648, 661 (1979)).

95. Id. at 788. In Terry, the Supreme Court held that police are authorized to seize a person for a limited time based on specific and articulable suspicion to believe that crime is afoot and that officers can conduct an accompanying limited search of the person's outer clothing if there is reason to believe that the person is armed and dangerous. Terry v. Ohio, 392 U.S. 1, 30 (1968).

96. Terry, 392 U.S. at 18-19.

97. The same is true of the Tenth Circuit's interpretation of similarly-worded statutes from 
to stop cars for lane violations that are physically unavoidable, present no hazard to others, and even when the violations are committed in the interest of promoting driver safety. Piecing together various decisions from the Tenth Circuit, it seems that a Kansas officer may stop a car even if the car leaves its lane of traffic only once for a brief time.

In United States $v$. Tang, the Tenth Circuit held that a single, but significant, fog-line violation by the driver of a U-Haul was sufficient reason for an officer to stop the U-Haul. ${ }^{98}$ The stop in Tang occurred around 10:00 p.m. ${ }^{99}$ It was a dark night, on a stretch of road with no street lights or moonlight. ${ }^{100}$ There was a "mild to moderate wind."101 At the suppression hearing, the officer testified that he saw the defendant's U-Haul "cross over the right side fog line" and remain there for two hundred to three hundred yards. ${ }^{102}$ After the lane drift, the officer followed the U-Haul another mile, but the U-Haul did not leave its lane again. ${ }^{103}$ Despite the isolated lane violation and the mile with no other infractions, the officer stopped the U-Haul. ${ }^{104}$ In testimony, the officer admitted that "it is common for people to drive over the line on the freeway," but said that this violation was different because of "the time of night and length of time [defendant]'s vehicle was over the fog line." 105 The trial judge found that the officer testified "credibly and truthfully" and denied the defendant's motion to suppress. ${ }^{106}$ On appeal, the Tenth Circuit ruled that because there were no unusual weather or road conditions that made it impractical to remain entirely within a single lane of traffic, the officer acted lawfully in stopping the U-Haul. ${ }^{107}$ In

other states, for example Utah's "fog-line" statute. See, e.g., United States v. Tang, No. 08-4179, 2009 WL 1353755 (10th Cir. May 15, 2009) (holding that stopping a vehicle for a fog-line violation was proper despite the absence of hazard to others).

98. Id. at *6. Tang interpreted Utah's statute, not Kansas's, but the statutory language in each statute is very similar, and the Tenth Circuit's decisions have treated the statutes similarly. Utah's statute requires a "person operating a vehicle" to "keep the vehicle as nearly as practical entirely within a single lane." UTAH CODE ANN. § 41-6a-710(1)(a) (West 2004). Kansas's statute requires a "vehicle" to be driven "as nearly as practicable entirely within a single lane." KAN. STAT. ANN. § 81522(a) (2008).

99. Tang, 2009 WL 1353755 , at *1.

100. Id.

101. Id.

102. Id.

103. Id.

104. Id.

105. $I d$. at $* 2$.

106. Id. at *3

107. Id. at *4 (distinguishing United States v. Gregory, 79 F.3d 973 (10th Cir. 1996), in which the Tenth Circuit found unreasonable an officer's decision to conduct a traffic stop after a truck briefly crossed onto the right shoulder emergency lane, given that the terrain was mountainous, the weather was windy, and the road winding). See also United States v. Cline, 349 F.3d 1276, 1287 
Fourth Amendment terms, the stop was "reasonable," so it complied with the Constitution.

In United States v. Alvarado, the Tenth Circuit increased the attractiveness of fog-line violations as a basis for a traffic stop, ruling that one incident of driving across the fog line by "about a foot" for "a few seconds" gave the police sufficient reason to stop the car. ${ }^{108}$ In Alvarado, a Utah ${ }^{109}$ Highway Patrol Trooper testified that a Jeep Cherokee crossed about one foot over the right fog line of the highway and remained there for a few seconds despite "ideal driving conditions," including a sunny day, no wind, and a straight and flat stretch of road, which was dry and without pot holes or debris. ${ }^{110}$ The Tenth Circuit affirmed the district court's finding that "there were no adverse weather or road conditions that might have made it impractical for Alvarado to prevent his vehicle from drifting out of the righthand lane and over the fog line.".111 On its way to concluding that the trooper "had a reasonable articulable suspicion that Alvarado, by crossing one foot over the fog line, had violated [Utah's] § 41-6-61(1),",112 the Tenth Circuit rejected the defendant's argument that a typical driver " operating a motor vehicle at or near interstate speed limits has a difficult task of operating the vehicle entirely within a single lane for the entirety of his trip." $" 113$ In rejecting the defendant's argument, the Tenth Circuit explained that under its precedent, the determination is "a fact-specific inquiry into the particular circumstances present during the incident in question in order to determine whether the driver could reasonably be expected to maintain a straight course at that time in that vehicle on that roadway."114

Consistent with its ruling that a single violation of a fog-line statute can create reasonable suspicion or probable cause sufficient to subject a

\footnotetext{
(10th Cir. 2003) (holding that reasonable grounds for a traffic stop existed when an officer saw a truck swerve onto the shoulder of the road and almost hit a bridge abutment).

108. 430 F.3d 1305, 1306 (10th Cir. 2005).

109. As noted earlier, the Kansas statute and the Utah statute contain similar wording. In any event, the Tenth Circuit has often applied its precedent involving fog-line violations in one state to a fog-line violation in another. See United States v. Pulido-Vasquez, 311 F. App'x 140, 143 (10th Cir. 2009) (noting in the context of an evaluation of whether a fog-line violation that occurred in Kansas gave the police reasonable suspicion, that the "factual situation of the initial stop resembles instances in which we have found a violation of the Kansas statute or similar laws of other states" (emphasis added)).

110. Alvarado, 430 F.3d at $1306-07$.

111. Id. at 1309.

112. Id.

113. Id. (quoting defendant's argument in support of motion to suppress).

114. Id. The Tenth Circuit has also held that one abrupt swerve across the fog line lasting "about two seconds on the shoulder" is sufficient grounds for a stop. Pulido-Vasquez, 311 F. App'x at 142, 144.
} 
driver and her car to a Fourth Amendment seizure, the Tenth Circuit's cases establish that two fog-line violations are usually more than enough reason for a traffic stop, even if a driver is operating a large vehicle, like a motor home, which is susceptible to being blown off course by wind. In United States v. Ozbirn, the Tenth Circuit agreed that reasonable suspicion was created when a motor home driven on a Kansas highway drifted onto the shoulder of the road "twice within a quarter mile under optimal road, weather and traffic conditions." 115 The defendant did not dispute the facts but contended that "drifting outside the marked lane does not establish sufficient grounds for an officer to make a stop."116 Although the Tenth Circuit acknowledged that the Kansas fog-line statute was "susceptible to rather arbitrary application by law enforcement officers," the court decided that on the particular facts of the case, the trooper "had probable cause to stop Mr. Ozbirn."117

As the Tenth Circuit acknowledged, fog-line violations offer the police extensive discretion to enforce the traffic laws arbitrarily. ${ }^{118}$ Not only is every driver certain to violate a single-lane requirement on occasion, ${ }^{119}$ but especially in Kansas, which often experiences windy conditions, it may sometimes be physically impossible to drive entirely within a single lane. ${ }^{120}$ Moreover, because an officer's assertion that such a violation occurred is difficult, if not impossible, for a driver to refute with his own competing testimony, traffic stops for fog-line violations give the police infinite opportunities to pick and choose which drivers and cars they will stop. It appears that any thoughtful officer could follow a car long enough to spot a fog-line violation, or convince herself that the car and driver seem suspicious and that the officer would be justified in claiming such an infraction.

Some of the proof that police can and do pick and choose among drivers when they decide to enforce a fog-line statute is supported by the facts of the Tenth Circuit cases reporting such violations. In case after case, an officer stops a vehicle for drifting from its lane of traffic, but rather than ticket the driver or undertake an investigation directed at

\footnotetext{
115. 189 F.3d 1194, 1196, 1198 (10th Cir. 1999).

116. Id. at 1198.

117. Id. In the alternative, the Tenth Circuit ruled that the trooper had reasonable suspicion of a traffic violation to warrant a traffic stop for further investigation. Id. at 1199.

118. Id. at 1198.

119. As the officer admitted in the Tang case, it is common for drivers to drift from their own lane of travel, at least occasionally. United States v. Tang, 332 F. App'x 446, 448 (10th Cir. 2009).

120. See Mark F. Grady, Res Ipsa Loquitur and Compliance Error, 142 U. PA. L. REV. 887, 900 (1994) (evaluating car accidents from an economics perspective and noting that "[i]t is impossible to drive a car for any period of time without missing a required precaution").
} 
ensuring that the driver is not falling asleep or otherwise incapable of maintaining her lane, the officer embarks on an obvious attempt to investigate the driver and car for drug violations or other, similarly serious crimes. In case after case, the police offer the driver a warning before momentarily leaving the driver and then "reconnecting" to ask more questions and, ultimately, requesting permission to search for contraband. Typically, the nature and subject matter of the officer's questions show that the officer cares nothing about a lane violation and everything about possible drug trafficking.

For example, in United States v. Gregory, an officer testified that the defendant was not cited for a traffic violation but that during his interaction with the driver, he became suspicious that the vehicle contained contraband; therefore, the officer asked if the defendant was "carrying any illegal substances in the truck" and then "if he could take a look." 121 Ultimately, a search of the defendant's rented U-Haul uncovered marijuana and cocaine in plastic garbage bags in the trailer portion of the truck. ${ }^{122}$ In United States v. Alvarado, the trooper "gave Alvarado a written warning for crossing the fog line, returned Alvarado's documents, and told him 'you're free to leave, drive safely,"' before returning to the defendant's vehicle and asking the driver more questions and "for permission to search the vehicle." 123 The subsequent search of the defendant's Jeep revealed "illegal narcotics hidden in the rear." 124 In United States v. Ozbirn, the trooper "finished issuing [a] warning" and then "asked Mr. Ozbirn if he could ask him a few more questions." This colloquy was followed by an inquiry about whether the defendant was "hauling any illegal guns, drugs, weapons, or other contraband," after which Mr. Ozbirn reportedly "invited" the trooper to look inside his motor home. ${ }^{126}$ Packets of marijuana were eventually discovered. ${ }^{127}$ In United States v. Pulido-Vasquez, it was a similar story. ${ }^{128}$ A Kansas highway patrol trooper issued the driver a warning, returned his "documentation," told the driver he was free to go, and then asked the driver and the passenger "for permission to search the vehicle for drugs." "29 Likewise, in United States v. Egan, a Shawnee County Kansas

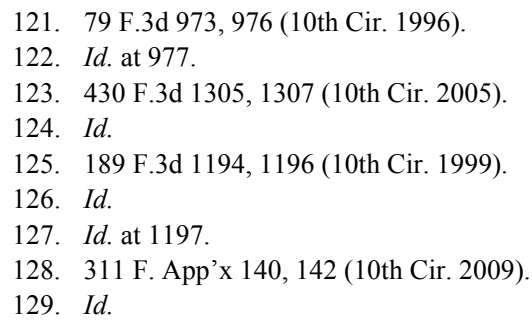


Sheriff's Deputy stopped a "'box-type' rental moving truck" for failing to maintain a single lane of traffic. ${ }^{130}$ Then, the deputy returned the driver's license and rental truck agreement, gave her a warning, and told her she was free to leave. ${ }^{131}$ Immediately thereafter, the deputy "asked if he could ask a few more questions" and then gained permission to look in the truck. ${ }^{132}$ A subsequent search of the moving truck led officers to find "twenty bundles of marijuana." 133

The fact that fog-line cases regularly involve an officer's transparent attempt to move quickly from discussing the traffic infraction to a search of the vehicle or occupants for drugs, guns, or other criminal violations strongly suggests, at least circumstantially, that police select certain cars and drivers as a pretext to investigate those cars and their occupants, not for fog-line violations, as they claim, but for more serious crimes for which the police lack any reasonable grounds to stop or search the car. Because in case after case, the police issue no citation for fog-line infractions, which supposedly prompted the stops, it seems unlikely that police view such violations as significant. In addition, because in each stop, the police seek permission to search after quickly dismissing the fog-line citation, the real motivation appears to be the search, not the ticket or the safety concern regarding the driver's failure to maintain a lane.

\section{Kansas State Law}

In Kansas, K.S.A. section $8-1522$ is the "fog-line statute," prohibiting drivers from committing lane violations. It provides that when a roadway is divided into two clearly marked lanes of traffic, "[a] vehicle shall be driven as nearly as practicable entirely within a single lane and shall not be moved from such lane until the driver has first ascertained that such movement can be made with safety."134 In the past two years, the Kansas Court of Appeals struggled to find a unified position regarding the type of conduct that creates reasonable suspicion or probable cause to believe that section 8-1522(a) has been breached. As discussed below in part C.2., the Kansas Supreme Court recently resolved the tension within the Kansas Court of Appeals. Nevertheless, the history of the appellate decisions showcases why Kansas officers

\footnotetext{
130. 256 F. App'x 191, 193 (10th Cir. 2007).

131. Id. at 193 .

132. Id.

133. Id. at 192-93.

134. KAN. STAT. ANN. § 8-1522(a) (2008).
} 
would choose fog-line violations as a pretext to investigate a hunch about more substantial crimes.

\section{The Kansas Court of Appeals}

One line of cases from the Court of Appeals required a fog-line violation, plus a determination that a lane drift was unsafe. A second competing line of cases from the same court rejected the need for a finding of dangerousness. In State v. Ross, a three-judge panel of the Court of Appeals held that the "as nearly as practicable" language in the traffic statute precluded an officer from conducting a traffic stop when she observes a driver cross the fog line only once during two miles of observation. ${ }^{135}$ Judges McAnany, Pierron, and Bukaty all agreed that the defendant's failure to maintain a single lane of traffic "[did] not necessarily constitute a violation of K.S.A. 8-1522(a)." ${ }^{\text {"136 }}$ The panel explained further: "'As nearly as practicable' connotes something less than the absolute. Automobiles are not railway locomotives. They do not run on fixed rails." 137 The panel said that cars are permitted to move from a single lane "after first determining it is safe to do so." panel concluded that whether reasonable suspicion exists for a traffic stop turns on whether "the totality of the circumstances... make it appear to the officer that not only did the defendant's vehicle move from its lane of travel, but it left its lane when it was not safe to do so."139 Applying the facts to its announced interpretation of section 8-1522(a), the panel in Ross decided that the officer lacked reasonable suspicion for a stop. ${ }^{140}$

There was no testimony that there was any obstacle or barrier on the shoulder that presented an immediate danger. There was no testimony that sand, gravel, or debris on the shoulder presented a hazard to a motorist who directed his or her vehicle onto the shoulder. There was not testimony that [the officer] was concerned that the driver might have been falling asleep or was intoxicated. [The driver's] vehicle was not weaving back and forth on the roadway. He was not using the paved shoulder as a regular lane of travel. He crossed the fog line only

\footnotetext{
135. State v. Ross, 149 P.3d 876, 878-80 (Kan. Ct. App. 2007).

136. Id. at 879 .

137. Id.

138. Id

139. Id.

140. Although the Court of Appeals ultimately found that the officer lacked probable cause to stop the defendant's car, the stop proved successful in uncovering contraband and illegality. The defendant lacked a valid driver's license and was concealing cocaine in his pockets. Id. at 878 .
} 
briefly, for only a short distance, and only once. In short, there was no reasonable suspicion that [the driver] was engaged in the conduct that is at the heart of the statute: moving a vehicle from its lane of travel without first ascertaining that it could be done safely.

Less than a year after the decision in Ross, a different three-judge panel (consisting of Judges Greene, Malone, and Leben) interpreted the same statute in a contrary way, expressly "declin[ing] to follow the Ross court's interpretation." In In State v. Marx, the government appealed from the trial court's ruling granting the defendants' motions to suppress. ${ }^{143}$ A sheriff's deputy had relied on K.S.A. section 8-1522 in stopping the defendants' motor home for failure to maintain a single lane. ${ }^{144}$ The officer said he stopped the vehicle "after he saw it cross the fog line, overcorrect, and cross the centerline." "145 After the stop, the deputy obtained and checked the occupants' licenses and vehicle registration, confirmed they were valid, and handed the documentation and a warning ticket to the occupants before telling the driver that she "was free to leave." 146 The deputy then asked the driver if she would answer a few more questions, asked if the motor home concealed drugs, and asked for permission to search it. ${ }^{147}$ When the driver refused consent, the deputy told her that he intended to use a drug dog to sniff the exterior of the vehicle. ${ }^{148}$ The driver then entered the motor home against the directives of the deputy and, apparently, began disposing of illegal drugs in the home's septic tank. ${ }^{149}$

The appellate panel in Marx found ample reasonable suspicion for the initial stop. In reaching this conclusion, the court expressly declined to follow the Ross court's interpretation of section 8-1522(a), explaining: "The 'nearly as practicable' language allows a driver to momentarily move outside a lane of traffic due to special circumstances such as weather conditions or an obstacle in the road. Otherwise, the driver must

141. Id. at 880. In State v. Hawk, a panel comprised of Judges McAnany, Pierron, and Standridge characterized the holding in Ross this way: "Under Ross, an officer does not have reasonable suspicion that K.S.A. 8-1522 has been violated unless the totality of the circumstances makes it appear that the defendant moved his or her vehicle from its lane of travel when it was not safe to do so." State v. Hawk, No. 100,096, 2009 WL 744362, at *4 (Kan. Ct. App. Mar. 13, 2009).

142. State v. Marx, 171 P.3d 276, 283 (Kan. Ct. App. 2007), aff'd in part, rev'd in part, 215 P.3d 601 (Kan. 2009).

143. Id. at 278 .

144. Id. at 278-79.

145. Id. at 279 .

146. Id.

147. Id.

148. Id.

149. Id. 
stay in one lane." 150 As for who must establish the "special circumstances" causing the car to drift, the panel said: "[I]f there was a special circumstance such as an obstacle in the road which caused [the driver] to swerve the motor home, it would seem that this is evidence only she could provide. The State is not required to prove a negative."151

The panel in Marx was unwilling to uphold the trial court's decision to grant the motion to suppress, even if there had been special circumstances requiring a safe driver to leave her lane of traffic. According to the panel, "[E]ven if [the driver] subsequently provided a legitimate defense for moving from her lane of traffic, such as to avoid an obstacle in the road, this would not invalidate the stop as long as [the officer] reasonably believed in good faith that a traffic violation had occurred." $" 152$

Combined, Ross and Marx demonstrate that when Marx was decided, six of the thirteen judges on the Kansas Court of Appeals were evenly divided on what it meant to commit a fog-line violation, which, in turn, gives an officer a legal basis to stop a car and conduct additional investigation in a face-to-face environment, offering police the chance to ask probing questions and for permission to search. Three judges seemed to think almost any drift was enough; three others wanted to require a lane drift plus a safety inquiry.

As a practical matter, the reasoning and holding in Ross made fogline violations significantly less attractive as a pretext to stop cars for ulterior reasons. Following Ross, an officer could not just cite a minor lane drift to explain a stop; rather, she had to explain in a credible and logical way why there were reasonable grounds to think the driver acted unsafely. This more detailed and extended testimony offered fodder for cross-examination of the officer. If the officer's narrative explanation was unconvincing, the judge might reject the officer's testimony and suppress the evidence. In contrast, under Marx, any reasonably competent officer could credibly articulate a lane drift as grounds for a traffic stop because no other explanation was needed. Such a cursory and conclusory bit of testimony would be almost impossible to refute through cross-examination or otherwise.

Less than two years after joining the decision in Marx, Judge Greene wrote a dissenting opinion in State v. Tinoco, indicating that he had changed his mind about fog-line violations. In Tinoco, Judge Greene

\footnotetext{
150. Id. at 283 .

151. Id.

152. Id. See also State v. Hawk, No. 100,096, 2009 WL 744362, at*4 (Kan. Ct. App. Mar. 13, 2009) (interpreting Marx as declining to follow Ross).
} 
adopted both the rationale and outcome in Ross, stating, "I would prefer to follow the rationale and outcome of the panel in State v. Ross . . . . Although I joined the majority in State v. Marx, . . I did so only because of the obvious factual distinction there." ${ }^{153}$ Judge Greene continued:

The result of the majority's decision is to license stops for conduct that is occasionally, if not routinely, exhibited by nearly every driver on the road. I would put a stop to such stops. Unless the driver exhibits conduct like that in Marx, we should not sanction any deprivation of liberty.

Although Tinoco allowed Judge Greene to express his new preference for Ross, the decision gave two other appellate judges an opportunity to distance themselves from the reasoning in the Ross decision. ${ }^{155}$ Although Judges Pierron ${ }^{156}$ and Standridge concluded that the defendant's appeal probably failed under the holding of either Ross or Marx, they emphasized that the appellate court "has declined to follow Ross in its more recent decision [Marx]." ${ }^{\text {157 }}$ The two judges further noted that "Tenth Circuit cases that were decided after Ross ha[d] been critical" of the decision. ${ }^{158}$ Thus, as of June 5, 2009, when the Court of Appeals issued Tinoco, three judges ${ }^{159}$ appeared to favor the Ross safety test for fog-line violations, and four ${ }^{160}$ seemed to favor the Marx nonsafety test.

\section{Recent Word from the Kansas Supreme Court}

The Kansas Supreme Court recently reviewed State v. Marx, undertaking its own interpretation of K.S.A. section 8-1522(a) to "resolve the conflict between Ross and Marx as to the conduct proscribed by [subsection (a)], i.e., to determine the elements of the offense."161

153. See State v. Tinoco, No. 100,435, 2009 WL 1591644, at *5 (Kan. Ct. App. Jun. 5, 2009) (Greene, J., dissenting).

154. Id.

155. Judges Pierron and Standridge affirmed the trial court's denial of the defendant's motion to suppress. The motion turned on whether a Kansas Highway Patrol Trooper had sufficient legal cause to stop a defendant for failing to maintain a single lane when the driver swerved two tire widths over a dividing line and into another lane of traffic on one occasion. Tinoco, $2009 \mathrm{WL}$ 1591644 , at *4-5.

156. As noted earlier, Judge Pierron was part of the panel that decided Ross.

157. Tinoco, 2009 WL 1591644 , at *4.

158. Id.

159. Judges McAnany, Bukaty, and Greene.

160. Judges Pierron, Malone, Leben, and Standridge.

161. 215 P.3d 601, 608 (Kan. 2009), aff'g in part, rev'g in part 171 P.3d 276 (Kan. Ct. App. 
The court sought to "intuit the most logical meaning to ascribe to this legislative language." 162 After parsing the statute, the court concluded that section 8-1522(a) establishes "two separate rules of the road."163 The first rule "requires a driver to keep entirely within a single lane while traveling on a roadway with two or more clearly marked lanes," but this rule is "temporarily suspended when it becomes impracticable to stay within the lane markers and when the driver is properly effecting a lane change."164 Therefore, "[p]roof that driving outside the lane markers created no safety hazard is not a defense to the single lane rule." 165 The safety issue arises, according to the Kansas Supreme Court, only in the second instance.

The second rule provides that before a driver may change lanes or move from the current lane of travel to another location, he or she must ascertain that the movement can be made with safety. A traffic infraction occurs under K.S.A. 8-1522(a) when either rule of the road is violated. ${ }^{166}$

The court emphasized: "[T]he statute does not make safety a part of the equation for determining a violation of the single lane rule."167

Turning to whether the facts of the Marx case gave the officer reasonable grounds to conduct a stop, the court noted that "K.S.A. 81522(a) is not a strict liability offense" and that the "as nearly as practicable" language in the statute "contradicts the notion that any and all intrusions upon the marker lines of the chosen travel lane constitute a violation." " 168 The court acknowledged that weather conditions and obstacles in the road could make it impracticable to maintain a single lane of traffic and then went further: "[T]he statute even dilutes the practicability standard. It does not say 'when practicable' a vehicle will be driven entirely within a single lane. It only requires compliance with the single lane rule as nearly as practicable, i.e., compliance that is close to that which is feasible." "169 Thus, concluded the court, "a detaining officer must articulate something more than an observation of one

\footnotetext{
2007).

162. Id. at 610 .

163. Id. at 612 .

164. Id

165. Id.

166. Id.

167. Id

168. Id.

169. Id.
} 
instance of a momentary lane breach."170 But, the fact that a driver leaves a single lane without endangering himself or others is irrelevant. ${ }^{171}$

Accordingly, after the Kansas Supreme Court's decision in Marx, to justify a stop, an officer need not provide an explanation about how the fog-line drift created danger, a relatively tough standard, probably requiring a significant amount of explanation. ${ }^{172}$ However, an officer must be able to explain why it was feasible, given the circumstances, for the driver to stay within the lane markers. ${ }^{173}$ While requiring some explanation, the standard adopted by the court will probably be met whenever an officer credibly testifies that there was little wind, no road obstructions, and a relatively straight stretch of road. ${ }^{174}$ This type of testimony will allow some opportunity for a talented cross-examiner to reveal inconsistencies in the officer's explanation that might suggest the supposed fog-line violation was concocted as an excuse to investigate for drugs, but it falls short of requiring extensive testimony that the danger test (established by Ross) would have encouraged. Thus, like current Tenth Circuit case law, Kansas state court decisions offer no special protection against pretextual traffic stops based on fog-line infractions. ${ }^{175}$

Although the Kansas courts have provided no special protections from pretextual stops that begin with traffic infractions, the Kansas Supreme Court has imposed one limit on pretextual traffic stops, thereby implicitly recognizing that such stops can, at least sometimes, infringe on Fourth Amendment (and comparable Kansas constitutional) rights. ${ }^{176}$

170. Id.

171. See id. (finding that safety is "not a part of the equation" in ascertaining whether or not there has been a breach of the single lane requirement).

172. Id.

173. Id. at 612 (stating that an officer must articulate whether or not he knew of circumstances "making it impracticable to stay within lane markers," such as a weather-related issue or a physical object in the lane).

174. See id. at 613 (explaining the testifying officer just needs to give a rendition of what he knew, when he knew it, and "whether the known facts provided him with a reasonable and good faith belief that a traffic infraction had occurred").

175. See id. at 605 (concluding that when an officer can articulate facts demonstrating probable cause to conduct a traffic stop, the seizure is valid even if pretextual).

176. Kansans are protected by both the Fourth Amendment in the federal Constitution and a comparable provision in the Kansas Constitution. KAN. CONST. Bill of Rights $\S 15$ protects Kansans against unreasonable searches and seizures, stating:

The right of the people to be secure in their persons and property against unreasonable searches and seizures, shall be inviolate; and no warrant shall issue but on probable cause, supported by oath or affirmation, particularly describing the place to be searched and the persons or property to be seized.

Unlike some other states' constitutions, which provide citizens with more protection from governmental intrusions on privacy and liberty than does the federal Constitution, the Kansas 
Kansas officers are prohibited from claiming that there was reason to believe that a citizen needed help and that a stop was conducted for "community caretaking purposes" 177 as a ruse for a drug investigation. ${ }^{178}$ As the court noted in State v. Marx, "permitting the public safety rationale to serve as a pretext for an investigative detention runs the risk of emasculating our Fourth Amendment protections."

Of course, a similar emasculation argument can be, and has been, made about pretextual traffic stops for minor traffic infractions. As Justice Johnson recently said in his dissent in State v. Greever, a traffic infraction case in which the defendant reportedly failed to signal a turn, "I am concerned about expanding the circumstances under which law enforcement officers are legally permitted to engage in profiling to select targets of investigatory detentions." 180 While acknowledging the holding in Whren, Justice Johnson continued:

In my view, that holding permits an officer to select any particular profile-Hispanics, teenagers, soccer moms, long-haired men, etc.and target those individuals for seizure to investigate any crime perceived to be prevalent among the particular group, so long as the officer can identify a preceding traffic infraction, no matter how innocuous or esoteric the violation.

Justice Johnson's concern that Whren and its Kansas progeny will result in racial (or other arbitrary) profiling is not without factual support. A study published in 2003 concluded that several Kansas police departments were stopping a disproportionate number of black and Hispanic people. ${ }^{182}$ Recognizing the detrimental effects of racial profiling, the Kansas legislature has expressly prohibited the practice. ${ }^{183}$

Supreme Court has interpreted Section 15 as providing "identical" rights as those protected by the Fourth Amendment. See State v. Morris, 72 P.3d 570, 576 (Kan. 2003) ("Section 15 of the Kansas Bill of Rights provides protection identical to that provided under the Fourth Amendment to the United States Constitution."). Thus, a Kansas defendant must convince the trial judge that the federal Constitution has been violated or her Section 15 claim fails.

177. See Marx, 215 P.3d at 606 (explaining that the "primary motivation for a valid public safety stop must be for community caretaking purposes"). Community caretaking stops would include stops to tell a motorist that the gas cap to his car is open or missing, that his trunk is open, that his door is ajar, and to return a hubcap that an officer sees a vehicle lose.

178. Id.

179. Id.

180. State v. Greever, 183 P.3d 788, 800 (Kan. 2008) (Johnson, J., dissenting).

181. Id.

182. See A Multijurisdictional Assessment, supra note 23, at 53-54, 80-81, 90, 105, 111-12, 127. Studies in other states have made similar findings. See, e.g., O’Neill, supra note 45, at 747, $771-72$.

183. See KAN. STAT. ANN. $\S \S 22-4606,-4608$ (2007) (defining racial profiling and making it 


\section{SOME ObSERVATIONS About THE Fog-Line DATA}

At a minimum, the Fourth Amendment requires police to act reasonably when they stop a car or search a person or vehicle. ${ }^{184}$ Arguably, acting reasonably would preclude pretextual searches or seizures, in which the police rely on personal animus or unreliable stereotypes - race, ethnicity, skin color, or out-of-state status-in selecting targets for their traffic stops. Perhaps for the reasons articulated by Justice Johnson in State v. Greever, ${ }^{185}$ under such a theory of reasonableness, Kansas police would violate the Fourth Amendment whenever they intentionally select all or only Hispanic drivers to enforce K.S.A. section 8-1522(a).

Despite the intuitive strength of defining Fourth Amendment reasonableness in this way, Whren established a different test, one that expressly rejects any notion that individual officers are precluded from conducting pretextual traffic stops, even if officers choose the targets of their stops by unlawful, even unconstitutional, ${ }^{186}$ criteria. If an officer has reason to believe that a driver has violated a traffic regulation, the officer may lawfully stop the car, even if his real desire is to investigate for drug trafficking, gun possession, fraud, or another crime for which he lacks evidence and reasonable suspicion. The Fourth Amendment makes it irrelevant that the officer picks his target based on good looks, color, ethnicity, apparent social status, vehicle type, out-of-state plates, or for some other arbitrary reason, such as harassment. Because Whren permits, if not fosters, racist stops, the decision has been repeatedly criticized. ${ }^{187}$

unlawful for any law-enforcement officer to engage in it).

184. See Samson v. California, 547 U.S. 843, 855 n.4 (2006) (describing reasonableness as the "touchstone" of the Fourth Amendment).

185. See State v. Greever, 183 P.3d at 800 (Johnson, J., dissenting).

186. Although beyond the scope of this Article, pretextual stops might, for instance, violate the Equal Protection Clause of the Fourteenth Amendment, which prohibits state actors to "deny to any person ... the equal protection of the laws." U.S. CONST. amend. XIV, § 1. See generally Jennifer A. Larrabee, Note, "DWB (Driving While Black)" and Equal Protection: The Realities of an Unconstitutional Police Practice, 6 J. L. \& POL'Y 291, 295 (1997) (arguing “that the Equal Protection Clause should prevent the police from considering the race of a motorist when deciding whom to detain for a traffic violation").

187. See, e.g., Angela J. Davis, Race, Cops, and Traffic Stops, 51 U. MiAmi L. REV. 425, 427 (1997) (arguing that Whren left African-Americans and Latinos without an effective remedy for discriminatory pretextual traffic stops); David A. Harris, "Driving While Black" and All Other Traffic Offenses: The Supreme Court and Pretextual Traffic Stops, 87 J. CRIM. L. \& CRIMINOLOGY 544, 545-46 (1997) (arguing that Whren makes any citizen fair game for a traffic stop but will result in police stopping hugely disproportionate numbers of African-Americans and Hispanics); Christopher Hall, Note, Challenging Selective Enforcement of Traffic Regulations After the Disharmonic Convergence: Whren v. United States, United States v. Armstrong, and the Evolution 
For instance, scholars have pointed out that Whren may result in the under-enforcement of the law and may cause police to unduly intrude on the privacy and liberty of innocent people of color. ${ }^{188}$ As applied to the data gathered for this Article, the under-enforcement argument means that Kansas officers may have discovered more illegality had they been looking for unlawful conduct by all drivers, not just out-of-state cars and cars driven by brown-skinned people. Potentially, the officers' use of stereotypes dulled their senses and caused them to overlook reasonable suspicion in cases of non-Hispanic drivers, resulting in too little enforcement of Caucasian or African-American criminals. ${ }^{189}$

On the undue intrusion point, the fog-line data does not account for any of the fog-line traffic stops in which Kansas police searched without finding contraband. Searches during which the police found no drugs are never challenged in criminal court. ${ }^{190}$ Therefore, it is likely that the data significantly underrepresents the number of times Kansas officers stopped cars for pretextual reasons, then asked the occupants for, and received permission to search, but found no drugs, guns, or aliens. "[T]he [exclusionary] rule by its very nature only has the potential to address a portion of police violations." knowing how many times Kansas officers relied on stereotypes in conducting a stop and one or more searches that interfered with the liberty and personal privacy of people of color but failed to uncover a crime.

Critics of Whren have also argued that the decision encourages racial profiling and that, in turn, racial profiling undermines faith in the entire criminal justice system. David Harris, one of the prominent experts on racial profiling, has described the consequences this way:

of Police Discretion, 76 TEX. L. REV. 1083, 1085 (1998) (asserting that Whren rendered the Fourth Amendment and the Equal Protection Clause "essentially useless" in countering selective enforcement of the law).

188. See Davis, supra note 187 , at 427 ; O'Neill, supra note 45 , at $747,771-72$ (reciting literature and studies of "disturbing racial disparities in traffic enforcement" including study of stops throughout Illinois in which officers "utilized consent searches against Hispanic drivers more than twice as often as against Caucasian drivers" although "searches of Caucasians were twice as likely to discover contraband as were the searches of minorities").

189. See O'Neill, supra note 45, at 771-72; David Cole, Profiles in Policing, ChAmPION, Apr. 2002 , at 12,16 (citing studies showing that whites are at least as likely to carry drugs as blacks or Hispanics).

190. Data from a study of the Wichita Police Department revealed that stops of pedestrians and cars leading to searches resulted in the seizure of contraband in only about $3.3 \%$ of stops. WITHROW, supra note 28 , at 47.

191. L. Timothy Perrin et al., If It's Broken, Fix It: Moving Beyond the Exclusionary Rule: A New and Extensive Empirical Study of the Exclusionary Rule and a Call for a Civil Administrative Remedy to Partially Replace the Rule, 83 IOWA L. REV. 669, 675 (1998). 
It has a corrosive effect on the legitimacy of the entire justice system. It deters people of color from cooperating with the police in criminal investigations. And in the courtroom, it causes jurors of all races and ethnicities to doubt the testimony of police officers when they serve as witnesses, making criminal cases more difficult to win. ${ }^{192}$

The five fog-line cases show why racial profiling would have this result. Officers in each fog-line case testified about wind and road conditions and lane drifts, but mentioned nothing about skin color, behavior suggesting drug trafficking, or the reliability of stereotypes at predicting crime. The officers rarely mentioned the significance of outof-state plates and even when they did, it was in response to crossexamination. There is no claim by even one Kansas officer that all (or most) drug-traffickers who travel the roads in Kansas are Mexican, Puerto Rican, or Central or South American. None of the officers testified that they saw a driver with brown skin, so they followed the car to look for suspicious behavior that might indicate drug trafficking and, while watching for such behavior, saw the driver deviate from his lane of travel. At least in some of the cases, if not in all of them, this seems to be the reality. Because the pattern of stops suggests that these factorsskin color, vague suspicion of drug trafficking, and out-of-state statusplayed a role, probably a significant one, in all five of the stops that formed the basis of the motions to suppress decided between August 1, 2008 and September 9, 2009, the officers' testimony should mirror these facts, if truthful and forthright.

If the officers were convinced that they acted reasonably by targeting people of color traveling from out of state, or people of Hispanic ethnicity who were driving rental vehicles, why did they avoid the subject and hedge on the reasons for the stops? In at least one case, United States v. Jose Maldonado, ${ }^{193}$ the officer expressly denied that race or ethnicity was a factor. ${ }^{194}$ Given the Supreme Court's express sanctioning of pretextual stops, why wouldn't Kansas officers candidly testify to the real circumstances for initiating an investigation?

It is possible that the officers did not discuss these reasons because these characteristics did not impact their decisions to stop the cars. Perhaps it is merely a coincidence that all of the fog-line stops involved

192. Harris, supra note 187, at 3. See also I. Bennett Capers, Crime, Legitimacy, and Testilying, 83 IND. L.J. 835, 838-41, 862 (2008) (providing an overview of some of the scholarly literature arguing that injustices directed at people of color create disrespect for the system).

193. 614 F. Supp. $2 d 1179$ (D. Kan. 2009).

194. Transcript of Proceedings (Feb. 26, 2009), supra note 46, at 28 (officer denying that he chose to follow defendant's vehicle because defendant was an Hispanic driver). 
Hispanic occupants. Given the small sample size, this conclusion is plausible. ${ }^{195}$ It is also possible that the officers did not document these reasons and offer them in explanation at the hearings because while skin color and other reasons played some role, they played only a subconscious one in the officers' thinking. Perhaps the officers were not cognizant of their true selection criteria and, therefore, did not document the reasons or testify about them on direct examination. Finally, it is at least equally likely that the officers consciously considered the factors and acted on them, but knowing that the public (and Kansas's district court judges) would be troubled by such seemingly arbitrary and morally-suspect standards for a criminal investigation, the officers struggled to identify other, more palatable bases to stop a car and investigate its occupants. ${ }^{196}$ Because Whren allows a seizure for any traffic infraction, officers and prosecutors were not legally obligated to tell the whole story. The government's case can survive a motion to suppress as long as a preponderance of the evidence shows that the officer had some reasonable basis for the stop and that he did not subsequently exceed the scope of reasonableness during a follow-up investigation.

The pattern in Kansas fog-line stops makes it appear that Kansas police are engaging in ethnicity-based profiling. Yet the testimony of Kansas officers fails to explain why such profiles are valid or to explain that the ethnicity of the drivers and occupants was nothing more than a coincidence. Even if the United States Supreme Court precedent makes such an explanation legally irrelevant, the lack of transparency in the officers' testimony causes police to appear dishonest. To the extent police strain to cover up the real reasons for a traffic stop, their testimony will appear contrived and untruthful, creating public and judicial distrust of their otherwise laudable work. Perhaps this taint of untruth explains why the district judges granted $40 \%$ of the defendants' motions to suppress in the five fog-line cases.

Finally, if it turns out that discriminatory fog-line police stops in Kansas are not a coincidence and that they reflect a police policy of discrimination, the stops may be unconstitutional notwithstanding

195. It is less plausible, however, given that many of the published Tenth Circuit decisions also appear to involve Hispanic defendants.

196. See Harris, supra note 187, at 19 ("Pretextual traffic stops fuel the belief that the police are not only unfair and biased, but untruthful as well. Each pretextual traffic stop involves an untruth, and both the officer and the driver recognize this.... Stopping a driver for a traffic offense when the officer's real purpose is drug interdiction is a lie-a legally sanctioned one, to be sure, but a lie nonetheless."). 
Whren. ${ }^{197}$ Although the Supreme Court has ruled that an individual officer's conduct will be judged by an objective, Fourth Amendment standard, the Court has yet to decide that programmatic motives are irrelevant in the investigation of criminal conduct. If police departments within Kansas encourage or acquiesce in a policy to follow and investigate Hispanic drivers as a pretext for drug investigations, the principles of Whren do not apply. ${ }^{198}$ Whren did not hold that law enforcement agencies act "reasonably" when they adopt discriminatory policies governing investigations. Arguably, programmatic motives should and do matter, even in traffic stops, and even after Whren.

As the United States Supreme Court recognized in City of Indianapolis v. Edmond, ${ }^{199}$ "while '[s]ubjective intentions play no role in ordinary, probable-cause Fourth Amendment analysis,' programmatic purposes may be relevant to the validity of Fourth Amendment intrusions undertaken pursuant to a general scheme without individualized suspicion.... Whren does not preclude an inquiry into programmatic purpose in such contexts." ${ }^{200}$ Although Edmond too is readily distinguishable from the typical fog-line case because it concerned the legality of a suspicionless roadblock, the principles of Edmond should extend to cases in which every member of a police department is expected to pursue, follow, and investigate cars tagged from out-of-state but ignore those who cross the fog line but bear a Kansas tag. The principles of Edmond should also apply to a police policy that encourages all officers to stop disproportionate numbers of Hispanic drivers in an effort to catch drug dealers. As the Court indicated in Edmond, "cases dealing with intrusions that occur pursuant to a general scheme absent individualized suspicion have often required an inquiry into purpose at the programmatic level."201 The limited data, which

197. KAN. STAT. ANN. § 22-4610 (2008) (requiring all Kansas law enforcement agencies to adopt a written policy prohibiting racial profiling).

198. Because Kansas requires a written policy prohibiting racial profiling, it will be difficult to prove that a department's actual policy is different. Nevertheless, a department may condone profiling informally or train their officers in ways that promote discriminatory stops notwithstanding a formal and written policy to the contrary. The 2003 study showing that multiple police departments in Kansas were engaging in discriminatory stops is evidence that officers may be acting pursuant to such a police custom, culture, or "policy," even if the policy is informal and contrary to the department's written policy. See A Multijurisdictional Assessment, supra note 23, at 11.

199. 531 U.S. 32, 40 (2000).

200. Id. at $45-46$ (citation omitted).

201. Id. at 46. See also Florida v. Wells, 495 U.S. 1, 4 (1990) (“[A]n inventory search must not be a ruse for a general rummaging in order to discover incriminating evidence."); Colorado v. Bertine, 479 U.S. 367, 372 (1987) (indicating that bad faith and the lack of a pure investigative purpose mattered to the validity of an inventory search, a search that does not rest on reasonable suspicion or probable cause). 
show a pattern of stopping cars with no intention of ticketing the drivers, suggests that some police departments within Kansas may have programmatic policies encouraging officers to investigate certain types of cars and drivers for drugs, regardless of suspicion. If so, these policies should be governed by cases limiting suspicionless seizures and searches of drivers and cars. Thus, under the reasoning of Edmond, such suspicionless investigations violate the Fourth Amendment.

\section{CONCLUSION}

In Whren, the United States Supreme Court sanctioned pretextual traffic stops. In practice the holding of Whren condones police investigations that target certain suspect classes of people, like Hispanics, for increased police scrutiny. In permitting pretextual stops, the Court ignored the risk that such practices will encourage police to distort the truth, overlooked the cost of under-enforcement of the laws, and ignored the consequences to the criminal justice system of race and ethnicity based discrimination.

Kansas law exacerbates these risks by making fog-line stops a model for protecting ulterior motives from a sifting judicial inquiry. In Kansas, it makes no difference that every driver occasionally crosses the fog line or that an individual driver left his lane without presenting any danger to another person, object, or animal. As long as a Kansas officer can credibly testify that the weather and road conditions made it practicable to stay within a single lane but that the driver did not, the officer has grounds for a stop, which gives him a chance to ask to search.

Despite Kansas officers' apparent practice of stopping certain cars and certain people, claiming that the cars left their primary lane of travel, and notwithstanding that federal and Kansas law make fog-line infractions easy to prove, judges in the District of Kansas have granted $40 \%$ of motions to suppress evidence in recent fog-line cases. The relative success of defendants at suppressing evidence in these cases should cause Kansas police to question the effectiveness of pretextual fog-line stops, especially given the risk that the public will perceive pretextual stops as motivated by skin color and ethnicity and considering the evidence from other states that discriminatory searches are counterproductive in uncovering crime. 